\title{
Do Translaminar Facet Screws Have the Same Stability as Pedicle Screws in Two-Level Anterior Lumbar Interbody Fusion? A Biomechanical Study
}

\author{
İki Seviyeli Anterior Lumbar Interbody Füzyonda Translaminar Faset \\ Vidalarının Stabilitesi Pedikül Vidalarıyla Aynı mıdır? Biyomekanik Bir
} Çalışma

Ying ZHAN, Ding TIAN

Tianjin 4th Centre Hospital, Department of Orthopaedics, Tianjin, China

Correspondence address: Ying ZHAN / E-mail: yingzh2012@163.com

\begin{abstract}
AIM:To determine whether translaminar facet screws can provide stability equivalent to pedicle screws in two-level anterior lumbar interbody fusion.

MATERIAL and METHODS: We performed a biomechanical study using 12 fresh human lumbar spines and tested intact spine, stand-alone two-level ALIF and anterior fusion augmented with pedicle screws or translaminar facet screws under 400N compressive preloads and 7.5Nm moments in flexion, extension, axial rotation and lateral bending, and measured the range of motion and the stiffness of operative level.

RESULTS: We found two-level ALIF had significantly reduced range of motion, greater stiffness at operative segments in flexion, axial rotation and lateral bending $(p<0.05)$, but decreased stiffness and increased range of motion in extension $(p<0.05)$, when compared to intact spine. The two augmented ALIF constructs have significantly reduced range of motion $(p<0.05)$ and increased stiffness at operative level $(p<0.05)$, when compared to intact spine or stand-alone two-level ALIF. There is no significant difference of range of motion and stiffness at operative level between the two augmented constructs in all loading directions $(p>0.05)$.

CONCLUSION: Translaminar facet screws can provide stability equivalent to pedicle screws, and we recommend translaminar facet screws as perfect alternatives to pedicle screws in two-level ALIF.
\end{abstract}

KEYWORDS: 2-level anterior lumbar interbody fusion, Translaminar facet screws, Pedicle screws

öz

AMAÇ: İki seviyeli anterior lumbar interbody füzyonda translaminar faset vidalarının pedikül vidalara eşdeğer stabilite sağlayıp sağlayamayacağını belirlemek.

YÖNTEM ve GEREÇLER: On iki taze insan lumbar omurgasını kullanarak biyomekanik bir çalışma yaptık ve fleksiyon, ekstansiyon, aksiyal rotasyon ve lateral eğilme durumunda $400 \mathrm{~N}$ kompresif ön yük ve 7,5 Nm moment altında sağlam omurga, tek başına iki seviyeli ALIF ve pedikül vidaları veya translaminal faset vidalarıyla güçlendirilmiş anterior füzyonu test edip hareket aralığını ve operatif seviye katılığını ölçtük. BULGULAR: İki seviyeli ALIF işleminin fleksiyon, aksiyal rotasyon ve lateral eğilme $(p<0,05)$ açısından hareket aralığını önemli ölçüde azalttığını ve daha fazla katılığa neden olduğunu ama sağlam omurgaya göre ekstansiyonda hareket aralığını arttırıp katılığı azalttığını $(p<0,05)$ bulduk. İki güçlendirilmiş ALIF konstrüksiyonu sağlam omurga veya tek başına iki seviyeli ALIF ile karşılaştırıldığında operasyon düzeyinde önemli ölçüde azalmış hareket aralığı $(p<0,05)$ ve artmış katılık $(p<0,05)$ mevcuttu. Tüm yükleme yönlerinde iki güçlendirilmiş konstrüksiyon arasında operasyon düzeyinde hareket aralığı ve katılık açısından önemli bir fark yoktu $(p>0,05)$.

SONUÇ: Translaminar faset vidaları pedikül vidalara eşdeğer stabilite sağlayabilir ve iki seviyeli ALIF için translaminar faset vidalarını pedikül vidalarına kusursuz bir alternatif olarak önerebiliriz.

ANAHTAR SÖZCÜKLER: 2 seviyeli anterior lumbar interbody füzyon, Translaminar faset vidaları, Pedikül vidaları

\section{INTRODUCTION}

Anterior lumbar interbody fusion (ALIF) augmented with posterior instrumentations has been widely used in recent years to treat a variety of spinal diseases $(9,12)$. Clinically, pedicle screw provides the most rigid fixation and regarded as golden standard, but the procedure requires extensive dissection of the paraspinal muscles and increased risk of neurologic damage and vascular injury. In comparison, translaminar facet screw fixation is less complex procedure and can be performed via minimal invasive techniques, and biomechanical studies on single-level ALIF show translaminar 
facet screw can provide comparable stability as pedicle screw (1, 3-5).

However, many ALIF procedures were performed on two or multi-levels, and in the reports from Shim et al (13), Thalgott et al (14) and Best et al (2), 35\%, 40\% and $41.8 \%$ of the total patients had more than one level fused. While, few studies has been published on the biomechanical properties of two or multi-level ALIF in English literatures. A study on the subject may be necessary to help spine surgeons to select instrumentations in surgery and decide surgery strategy.

Therefore, we proposed a study using fresh human lumbar spine specimens to investigate the biomechanical features of two-level ALIF augmented with pedicle screws or translaminar facet screws, and our objectives were: 1) to quantify the amount of destabilization in extension loading of two-level ALIF and the restabilization after augmentation with posterior fixation; 2) to compare the construct stability of two-level ALIF supplemented with translaminar facet screws to that supplemented with pedicle screws.

\section{MATERIAL and METHODS}

\section{Specimen preparation}

Twelve fresh human lumbar spines from L1-5 were procured for the test. Each spine was thawed overnight at room temperature and residual muscle tissue resected without disrupting the intervertebral discs and ligaments. The L5 segment was embedded in polymethylmethacrylate, and a loading frame was attached to the L1 vertebra.

\section{Biomechanical testing}

The spinal segment was mounted on a customized loading frame. A six-axis load cell was mounted in series to the caudal vertebra to verify the moments and forces applied. $400 \mathrm{~N}$ of constant compressive preload were applied to the spine along the path that follows the lordotic curve of the spine to minimize its contribution to the shear and bending forces (10). $7.5 \mathrm{Nm}$ moment was applied through the most cranial vertebra through a pulley-weight system in six directions: flexion, extension, right and left lateral bending, right and left axial rotation (Figure 1). 12 markers reflecting infrared light were attached to each of the L1, L2, L3, L4 and L5 vertebra. Spinal motion at each lumbar level was measured with an optical based motion tracking system at each loading step. Rotational angles at operation levels were then obtained.

The specimens were tested first in intact spine, then standalone two-level ALIF (anterior stand-alone cage, $9 \mathrm{~mm}$ height, Intromed, Germany), following the two-level ALIF augmented with pedicle screws (Tenor, Sofamor Danek, USA) or translaminar facet screws $(4.5 \mathrm{~mm}$ cortical screw). The specimens were instrumented in a random manner with either pedicle screw or translaminar facet screw fixation construct. All surgical procedures simulated those used clinically at our institution, and were performed by one clinically active spine surgeon.

\section{Statistical analysis}

The values of right and left lateral bending were averaged to represent the value of lateral bending, and the value of right and left axial rotation were averaged to represent the value of axial rotation. Stiffness of the operative segment was derived from the linear region of load-displacement curve in the six directions. Statistical comparison of the parameters among the intact spine, stand-alone two-level ALIF, ALIF augmented with translaminar facet screws and ALIF augmented with pedicle screws, was performed using analysis of variance (ANOVA). Statistical significance was determined at $95 \%$ confidence level. All statistical analyses were performed using SPSS software version 17.0 (SPSS, Inc., Chicago, IL).

\section{RESULTS}

\section{Range of Motion at operative level}

The range of motion at operative level in intact spine, twolevel ALIF and two augmented ALIF constructs are displayed in Figure 2. The intact spine present the largest range of motion in flexion, lateral bending and axial rotation, while in extension the range of motion in intact spine is significantly lower than that in two-level ALIF $(p<0.05)$. The range of motion in ALIF augmented with pedicle screws or translaminar facet screws is significantly lower $(p<0.05)$ than those in intact spine or two-level ALIF under all loading directions, while

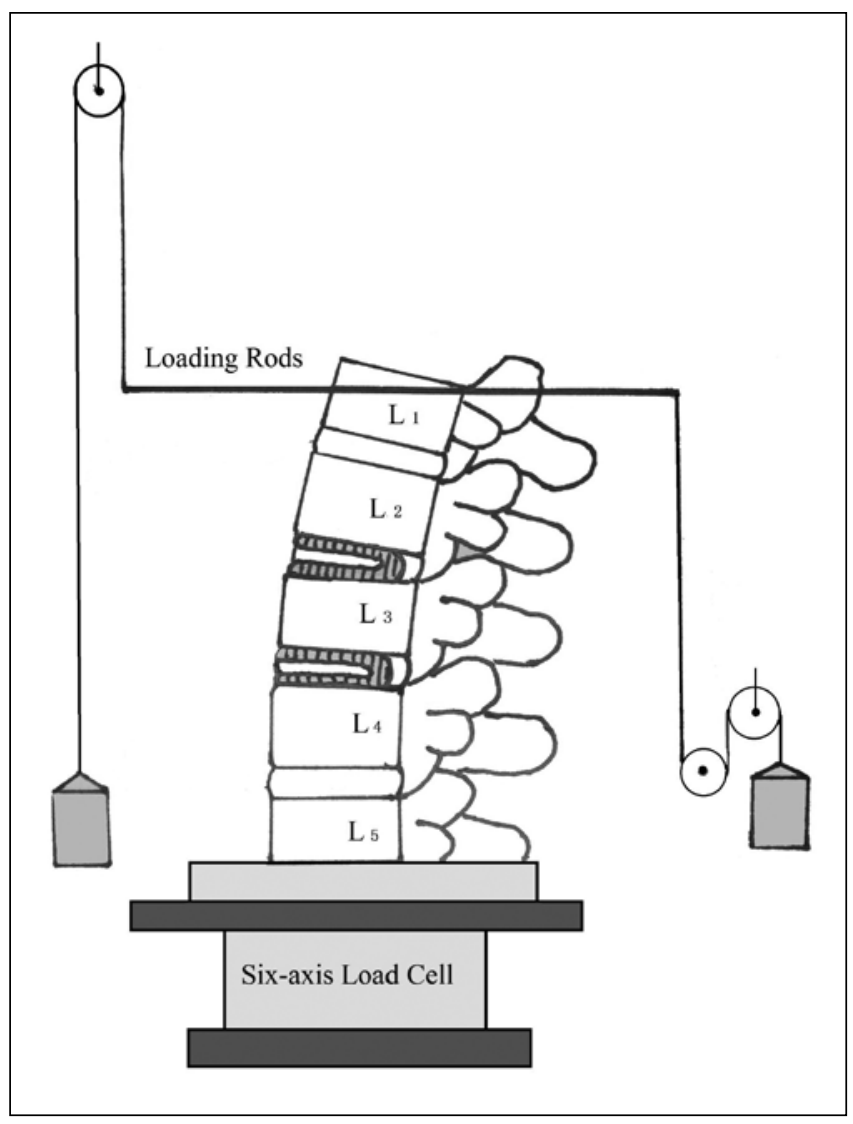

Figure 1: Illustration showing spinal biomechanics testing apparatus. 


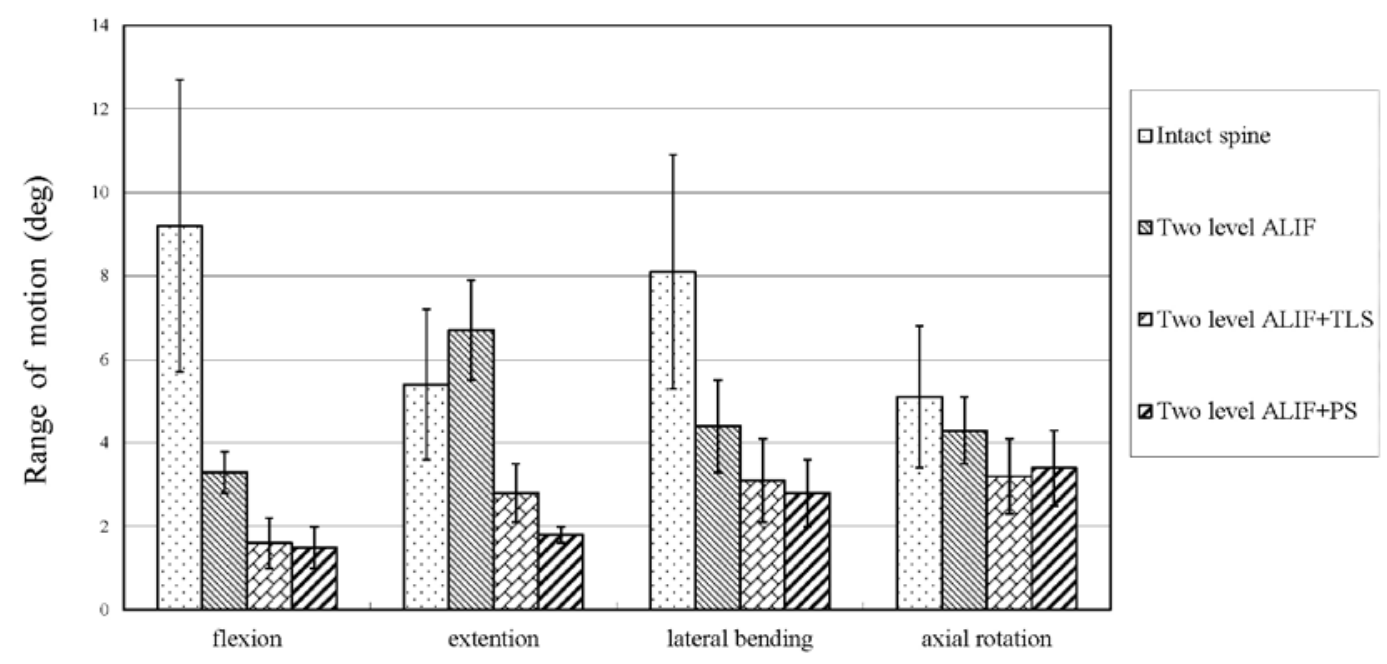

Figure 2: The range of motion at operation level.

there is no significant difference between two augmented ALIF constructs $(p>0.05)$ (Figure 2).

\section{Stiffness of Operative Level}

The mean stiffness of operative level in intact spine, standalone two-level ALIF, ALIF augmented with pedicle screws or translaminar facet screws are listed in Table I. The stiffness of operative segments in stand-alone two-level ALIF was higher than that in intact spine $(\mathrm{p}<0.05)$ in flexion, axial rotation and lateral bending, but lower $(p<0.05)$ in extension. In all loading directions, the operative segments augmented with pedicle screws or translaminar facet screws were significantly stiffer than those of intact spine $(p<0.05)$ or stand-alone twolevel ALIF $(p<0.05)$. However, there is no statistical difference between the two augmented ALIF constructs ( $p>0.05$ ) (Table I).

\section{DISCUSSION}

In the current study, we performed a biomechanical investigation on two-levels ALIF augmented with pedicle screws or translaminar facet screws using fresh human lumbar spine specimens. To the best of our knowledge, few studies have been performed on the subject.

Many biomechanical studies confirmed stand-alone cage specimen increased biomechanical stability in comparison to the intact motion segment in flexion, axial rotation and lateral bending, but decreased in extension in one-level ALIF. In the present study, the stiffness of operative level in two-level ALIF is larger, and the range of motion is lower than those of intact spine in flexion, axial rotation and lateral bending, but in extension the stiffness is decreased and the range of motion is increased in two-level ALIF, indicating the extension instability in two-level ALIF. Similar as onelevel ALIF, the removal of anterior longitudinal ligament and anterior annulus and distraction of facet joints can be the interpretation of extension instability in two-level ALIF (8). Subsequently, stand-alone two-level ALIF can't be recommended in spine surgery.

Clinically, posterior instrumentations, such as pedicle screw and translaminar facet screw, have often been used to augment ALIF. Among these instrumentations, ALIF supplemented with pedicle screws, was regarded as golden standard. Most studies in one-level ALIF indicated pedicle screw fixation yields superior biomechanical stability compared to translaminar facet screw fixation $(7,8)$. Eskander et al (4) performed a study on two-level ALIF and concluded translaminar screws have similar stability as pedicle screws. However, his experiment was done using only six human

Table I: The Stiffness of Operative Level in Intact Spine, Two-Level ALIF, Two-Level ALIF Augmented with Pedicle Screws and Two-Level ALIF Augmented with Translaminar Facet Screws

\begin{tabular}{|l|c|c|c|c|} 
& Intact spine $\left(\mathbf{N m} /{ }^{\circ}\right)$ & $\begin{array}{c}\text { Two level ALIF } \\
\left(\mathbf{N m} /{ }^{\circ}\right)\end{array}$ & $\begin{array}{c}\text { Two-level ALIF+PS } \\
\left(\mathbf{N m} /{ }^{\circ}\right)\end{array}$ & $\begin{array}{c}\text { Two-level ALIF+TLS } \\
\left(\mathbf{N m} /{ }^{\circ}\right)\end{array}$ \\
\hline Flexion & $2.7 \pm 0.5$ & $5.8 \pm 1.7$ & $7.8 \pm 1.5$ & $7.6 \pm 1.6$ \\
\hline Extension & $2.2 \pm 0.4$ & $1.7 \pm 0.7$ & $7.9 \pm 1.4$ & $7.5 \pm 1.5$ \\
\hline Lateral bending & $1.8 \pm 0.6$ & $3.0 \pm 0.9$ & $6.8 \pm 1.6$ & $6.6 \pm 1.2$ \\
\hline Axial rotation & $2.1 \pm 0.3$ & $2.6 \pm 0.5$ & $5.9 \pm 1.1$ & $6.1 \pm 1.3$ \\
\hline
\end{tabular}

$\mathbf{P S}=$ pedicle screws; $\mathbf{T L S}=$ translaminar facet screw; $\mathbf{A L I F}=$ anterior lumbar interbody fusion. 
cadaver specimens, and Eskander claimed the small sample size may affect the final result and suggest two-level ALIF augmented with pedicle screw tend to have less range of motion and may be stiffer than translaminar facet screw. As a result, the biomechanical properties of two-level ALIF augmented with pedicle screws or translaminar facet screws are not completely clear,

In the present study, the two posterior instrumentations significantly increase the stiffness and stability, and decrease the range of motion in two-level ALIF. However, different from one-level ALIF study, there is no significantly difference of stiffness and range of motion in operative segments between the two posterior instrumentations. Our result may indicate the advantages of translaminar facet screws, which can obtain a stable fixation of lumbar function segment just by two screws, while pedicle screws need four screws and two rods to realize the same fixation. Some literatures suggested two or multi-levels fixations may decrease the stability of instrumentation compared to one level fixations (6). In our opinion, too many screws, rods and the connection between rods and screws may decrease the stiffness and weaken the stability of fixation systems. Consequently, the pedicle screw did not show more stability than translaminar facet screw in two-level ALIF.

The present study show translaminar facet screw fixation is alternative forms of spinal stabilization which appears to provide similar stability at operation level. Moreover, the inexpensive posterior instrumentation, as the less invasive form of posterior fixation methods, can overcome the disadvantage of traditional pedicle screws (11). Consequently, we suggest that translaminar facet screws be the perfect alternatives of pedicle screws in two-level ALIF.

However, the present study has its inherent limitations. We performed the test using human spines, while no muscle forces were applied and the loads are simplified, which may have some influence on final results. In addition, our study focused only on immediate stability of the motion segment, while cages subsidence, relaxation of the anulus, or loosening of screws may affect stiffness and stability of the lumbar function segments and lead to different results in long-term tests, and to further clarify these effects, more studies would need to be performed in the future.

\section{REFERENCES}

1. Beaubien BP, Mehbod AA, KallemeierPM, LewWD, Buttermann GR, Transfeldt EE, Wood KB: Posterior augmentation of an anterior lumbar interbody fusion: Minimally invasive fixation versus pedicle screws in vitro. Spine 29:E406-412, 2004
2. Best NM, Sasso RC: Efficacy of translaminar facet screw fixation in circumferential interbody fusions as compared to pedicle screw fixation. Journal of Spinal disorders \& Techniques 19: 98-103, 2006

3. Burton D, Mclff T, Fox T, Lark R, Asher MA, Glattes RC: Biomechanical analysis of posterior fixation techniques in a 360 degrees arthrodesis model. Spine 30:2765-2771, 2005

4. Eskander M, Brooks D, Ordway N, Dale E, Connolly P: Analysis of pedicle and translaminar facet fixation in a multisegment interbody fusion model. Spine 32:E230-235, 2007

5. Ferrara LA, Secor JL, Jin BH, Wakefield A, Inceoglu S, Benzel EC: A biomechanical comparison of facet screw fixation and pedicle screw fixation: Effects of short-term and long-term repetitive cycling. Spine 28:1226-1234, 2003

6. Humke T, Grob D, Dvorak J, Messikommer A: Translaminar screw fixation of the lumbar and lumbosacral spine. A 5-year follow-up. Spine 23:1180-1184, 1998

7. Kandziora F, Schleicher P, Scholz M, Pflugmacher R, Eindorf T, Haas NP, Pavlov PW: Biomechanical testing of the lumbar facet interference screw. Spine 30:E34-39, 2005

8. Kim SM, Lim TJ, Paterno J, Kim DH: A biomechanical comparison of supplementary posterior translaminar facet and transfacetopedicular screw fixation after anterior lumbar interbody fusion. J of Neurosurgery Spine 1:101-107, 2004

9. Kuslich SD, Ulstrom CL, Griffith SL, Ahern JW, Dowdle JD: The Bagby and Kuslich method of lumbar interbody fusion. History, techniques, and 2-year follow-up results of a United States prospective, multicenter trial. Spine 23:1267-1278; discussion 1279, 1998

10. Patwardhan AG, Havey RM, Carandang G, Simonds J, Voronov LI, Ghanayem AJ, Meade KP, Gavin TM, Paxinos O: Effect of compressive follower preload on the flexion-extension response of the human lumbar spine. Journal of orthopaedic research: Official publication of the Orthopaedic Research Society 21:540-546, 2003

11. Phillips FM, Cunningham B, Carandang G, Ghanayem AJ, Voronov L, Havey RM, Patwardhan AG: Effect of supplemental translaminar facet screw fixation on the stability of standalone anterior lumbar interbody fusion cages under physiologic compressive preloads. Spine 29:1731-1736, 2004

12. Ray CD: Threaded titanium cages for lumbar interbody fusions. Spine 22:667-679, discussion 679-680, 1997

13. Shim CS, Lee $S H$, Jung B, Sivasabaapathi P, Park SH, Shin SW: Fluoroscopically assisted percutaneous translaminar facet screw fixation following anterior lumbar interbody fusion: Technical report. Spine 30:838-843, 2005

14. Thalgott JS, KlezI Z, Timlin M, Giuffre JM: Anterior lumbar interbody fusion with processed sea coral (coralline hydroxyapatite) as part of a circumferential fusion. Spine 27:E518-525, discussion E526-517, 2002 